\title{
THE ANTROPOGENIC INFLUENCE ON CUEJDIU RIVER WATER QUALITY
}

\author{
Ana-Andreea GHIURCÄ ${ }^{1}$, Andreea LĂMĂŞANU ${ }^{1}$, Florin-Constantin MIHAI ${ }^{1}$
}

Email: anaandreeaghiurca@yahoo.com

\begin{abstract}
Water pollution is caused in rural areas, especially by uncontrolled waste deposits located in river bed and in urban areas is discharged, irregular, untreated sewage. The Cuejdiu River is a tributary of the Bitrița River in the left side, with a total length of $24 \mathrm{~km}$. Evaluation of water quality of the Cuejdiu River was achieved by processing the results obtained from tests analyzed for 30 samples, taken on March 17, 2012, between the mouth of the River Bestrița and up to the exit of the village Cuiejdi. Analysis of water samples were performed in the laboratory of the Department of Geography, at the Faculty of Geography and Geology and were taken into account several parameters such as conductivity, $\mathrm{pH}$, total acidity, nitrates, chlorine. The values obtained were cartographically represented to highlight differences between the sector that cross of the rural area and the sector located on urban area. Water Management System Neamț realizes assessments of ecological and chemical status of the river Cuejdiu only in urban areas, classifying water quality in relation to general indicators. Thus, data obtained over a period of 10 years, from 2000 to 2010, and performing through charts, helped us to observe the time evolution of water quality in the area. The impact of human activities is evident in both urban and rural areas. In urban area the connections made by citizens, particularly those who live on the ground blocks, to the rainwater system, instead of sewerage systems, lead to the degradation of water quality. As regards the rural area, the situation is just as difficult, meaning that the waste discharged into the riverbed changes the chemical composition of water.
\end{abstract}

Key words: water quality, water pollution, anthropogenic influence.

Introduction. Human society has a significant role in the water cycle, influencing through activities in terms quantitatively by "consumption and redistribution" and qualitatively by changes in the physical, chemical and biological characteristics. Degradation of water quality is a negative consequence of human activities related to agriculture, the irrational use of pesticides, chemical or organic fertilizers etc. Water eutrophication pollute aquatic ecosystems from downstream areas which are not subject to treatment (Ungureanu I., 2003).

Imbalances formed on water chemistry change have serious consequences on the natural environment and population. Water pollution by human communities is responsible with the emergence of infectious diseases in urban areas (Cotigă C., 2007), uncontrolled storage waste in the river bed is the most representative form of damage to water quality.

Discharge of pollutants into water through sewage pipes, endanger the important resource of social and economic development, pollution was considered a sustainable and measurable phenomenon (Pohoață I., 2003).
The right of future generations to quality resources involves protecting them by means of effective management, to maintain a stable balance between the consumption and the quantity available. Application of the concept of sustainable development is essential in this situation because it supports economic use of resources for the future.

\section{MATERIAL AND METHOD}

Material and method. This study aims to analyze the human impact on water quality, with examples in basin Cuejdiu, located in the central part of Neamt, county. This basin has a total length of $24 \mathrm{~km}$, a mean width of $0.5 \mathrm{~m}$ and a mean deep of $0.16 \mathrm{~m}$ and includes the administrative units Piatra Neamț and Gârcina commune. Cuejdiu River in the territory of the city Piatra Neamt is arranged because of the past floods that produced substantial damage.

Water quality assessment is based on an analysis of 30 samples of water, taken on March 17,2012 , at an interval of $100-400 \mathrm{~m}$, from the mouth of the Cuejdiu River in the Bistrița River and up to the exit of the village of Cuiedji, Gârcina commune To these are added the data collected

\footnotetext{
1 „Alexandru Ioan Cuza”, University of Iaşi
} 
from the Neamt Water Management System, which carrying out analysis at a distance of 0.2 miles from the river mouth, monitoring the ecological status of water. These analyzes performed over a range of 10 years (2000-2010) places the water in the third grade of quality. Sample number 2 overlaps with that analysed by the authorized institution, so we made a temporal evolution of parameters through representative graphics.

The 30 evaluated samples were analyzed in the laboratory of the Department of Geography of the Faculty of Geography and Geology, consider the following indicators: temperature, $\mathrm{pH}$, conductivity, total acidity, nitrates, chlorides. Based on the results we noted the negative impact of the population activities (storage, waste disposal in the river bed, the discharge of waste waters) on water quality from rural and urban area.

\section{RESULTS AND DISCUSSIONS}

Results and discussions. The use of water resources requires compliance with the quality conditions, which must be consistent with the degree of use of water. Both urban and rural produce various sources of pollution of water quality, making it unfit for use.

Maintaining water quality is an effort that ensures public health and economic productivity growth (Soroceanu V., 2000).

The degree of the environmental factors degradation is correlated with the ecological education degree of the rural population. Often,

education is not the only cause that contributes to environmental pollution; the economic situation and the disinterest of local authorities for environmental issues are in most cases responsible for the existing reality on the field. In this research we highlighted some negative environmental practices, carried out by population of rural areas (Ghiurcă A., 2012).

Statistical processing of data from Neamt Water Management System showed that in urban areas, water is heavily polluted, even if the authorities propose solutions to resolve this. Analysis of chlorine is the only that places the quality of the Cuejdiu River in third grade. Its value ranges from 2000 to 2012, last year recorded a lower value compared to other years (fig.l).

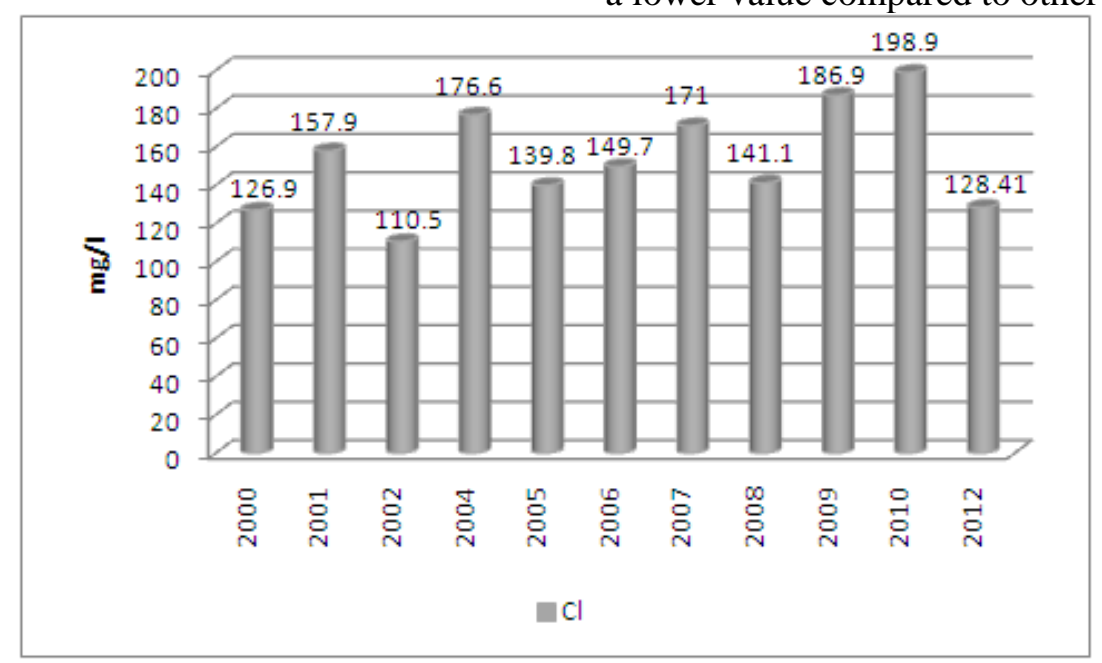

Figure 1 Variation of chlorine in the period 2000-2012 (sample 2)

Another parameter that it changes significantly is the nitrates present in water, which have higher values, for example in 2012 is register the highest value (fig.2).

Analysis of the results from the evaluation of the 30 samples highlight concrete the degree of pollution in the urban area compared to the rural area. Samples 1-15 provides information about water quality in the city area, the other being representative for the village (sample 1 is taken from the confluence with the River Bistrița). A series of indicators that give details on salinity are conductivity and chlorides. Analysis of these two parameters shows that urban areas are heavily polluted, the reason being the discharge of untreated water from nearby buildings, where they made illegal connections to the rainwater systems in place of sewerage (fig.3).

Evaluation of oxygen regime is represented by the analysis of chemical oxygen demand (COD$\mathrm{Mn}$ ), which determines "the amount of oxygen supplied to a chemical oxidant to decompose biodegradable organic matter in the water" (Szőcs A., 2010).

From the correlation of COD-Mn with nitrates it can see that in the urban area pollution is caused both by high levels of nitrates as high levels of chemical oxygen demand. However, the level of nitrates in rural area is higher than in urban area, values decrease with removal of habitable area. COD-Mn indicator recorded values much higher in rural area than in urban area due to the presence of non-biodegradable substances (fig.4). 


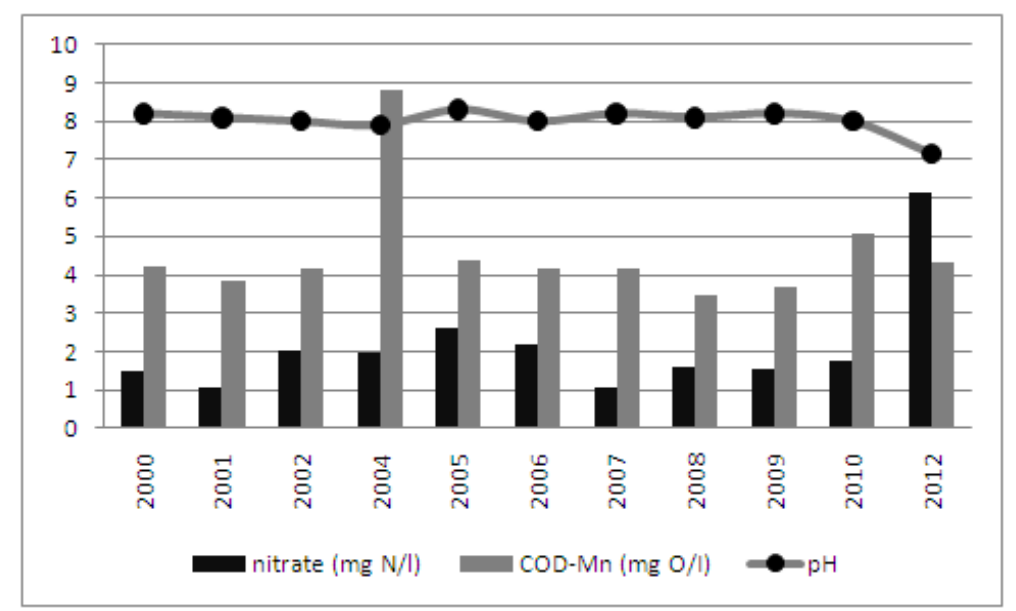

Figure 2 Variation of nitrates, COD-Mn, pH in the period 2000-2012 (sample 2)

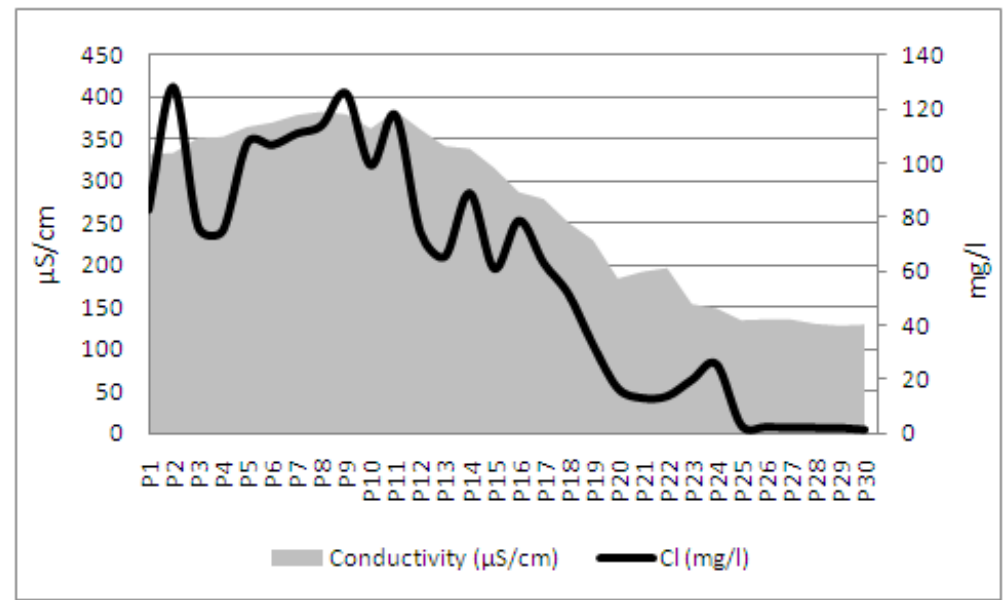

Figure 3 Variation of conductivity and chlorine in Cuejdiu basin

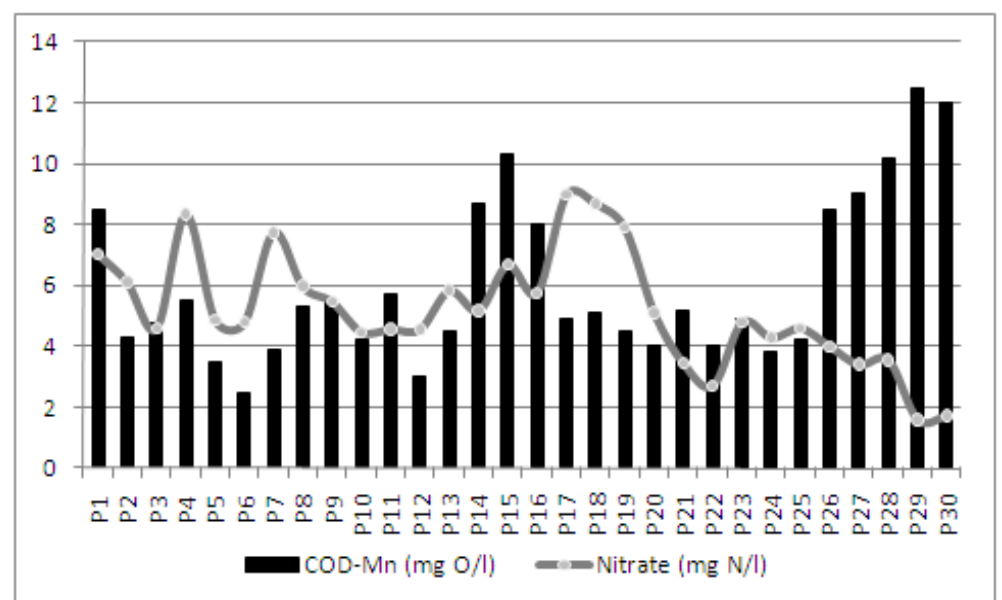

Figure 4 Variation of chemical oxygen demand and nitrate in the Cuejdiu basin

The acidity of water natural sources indicate sewage water pollution. In the urban area the total acidity values ae higher than rural areas, the most representative value being the 15 sample (fig. 5).

Water $\mathrm{pH}$ values ranging between 6.93 to 8.56, which induces a character from acid to alkaline water, and the temperature, showing values from $15.4^{\circ} \mathrm{C}$ to $18.9^{\circ} \mathrm{C}$, the data beeing collected in March (fig. 6). Disruption of chemical composition is the result of population activities from urban areas, one example being the location of small cement plant "ECOTRANS" just in close proximity, the resulting substances (from washing machines) get directly into the river (fig. 7). The proof of these issues is given by analyzing the sample number 15 , where the values are increased for all considered indicators. 


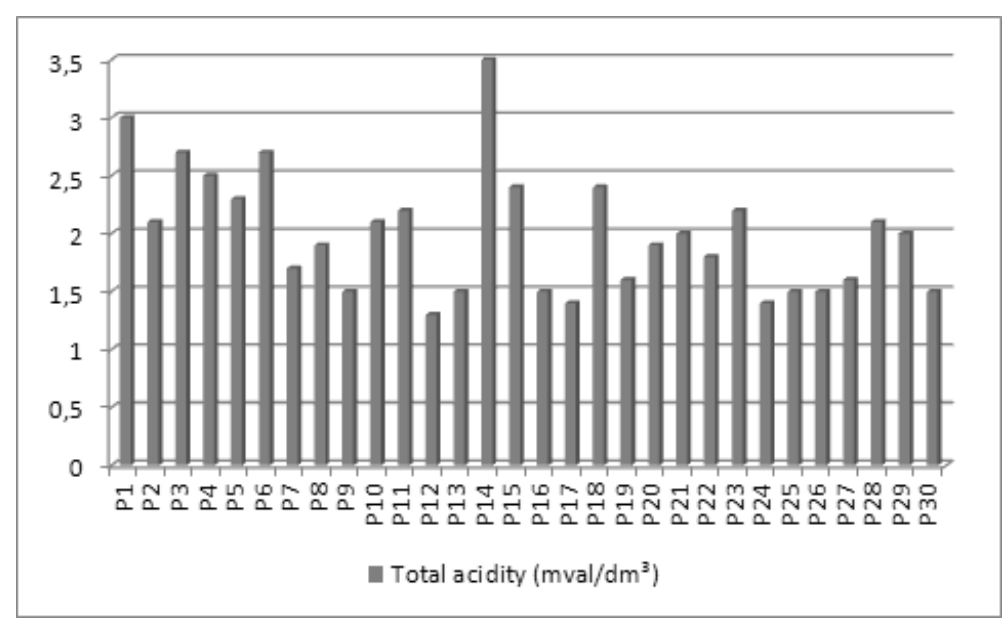

Figure 5 Variation of total acidity in the Cuejdiu basin

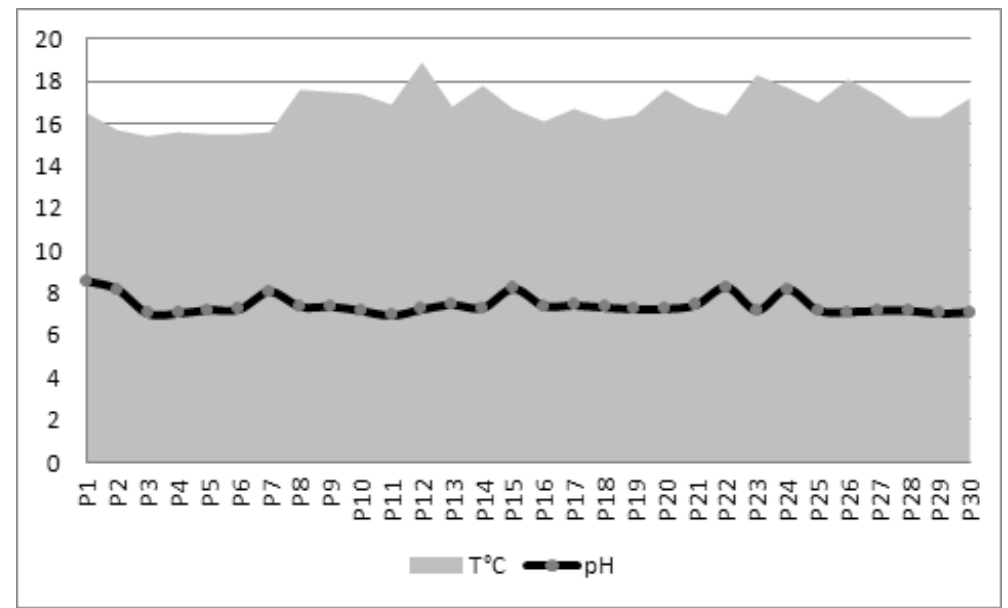

Figure 6 Variation of temperature and $\mathrm{pH}$ in the Cuejdiu basin

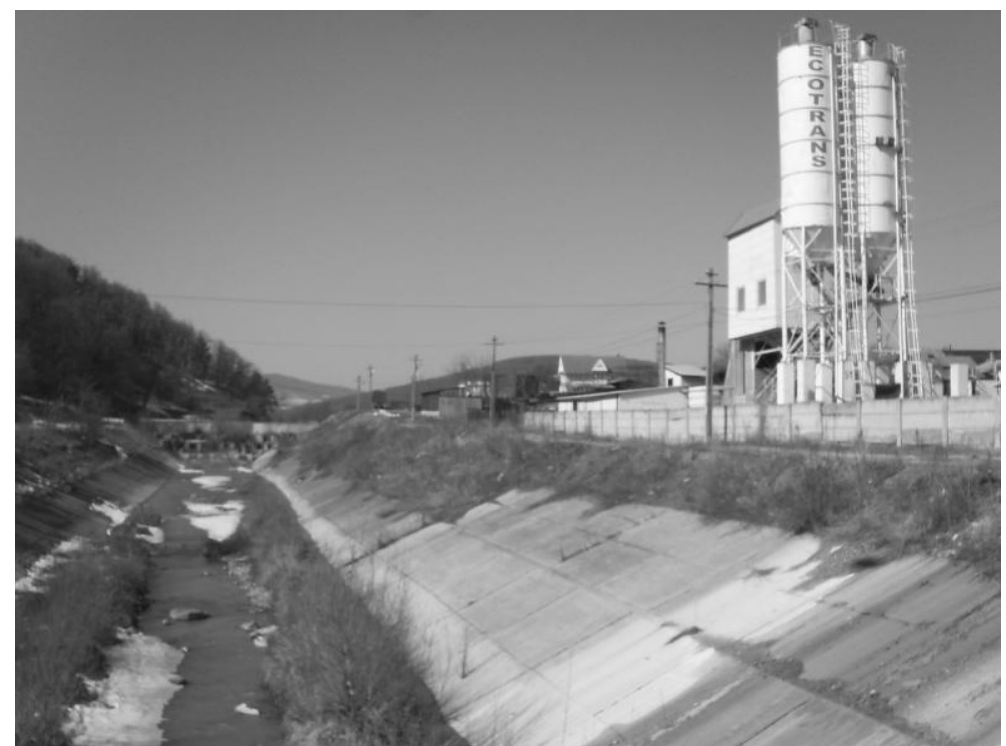

Figure 7 Cuejdiu River pollution influenced by "ECOTRANS" cement plant

In rural areas, population has a low education level which is reflected in activities of inappropriate storage and forest waste.

This is emphasized by the fact that local authorities don't exercise enforcement action environmental projects to improve the situation on the ground. Thus, water quality is significantly altered, without anyone to be concerned about this (fig. 8).

Water quality can be improved if people would be involved in activities associated with protecting the water and if it considered its opinion on issues facing the area. 

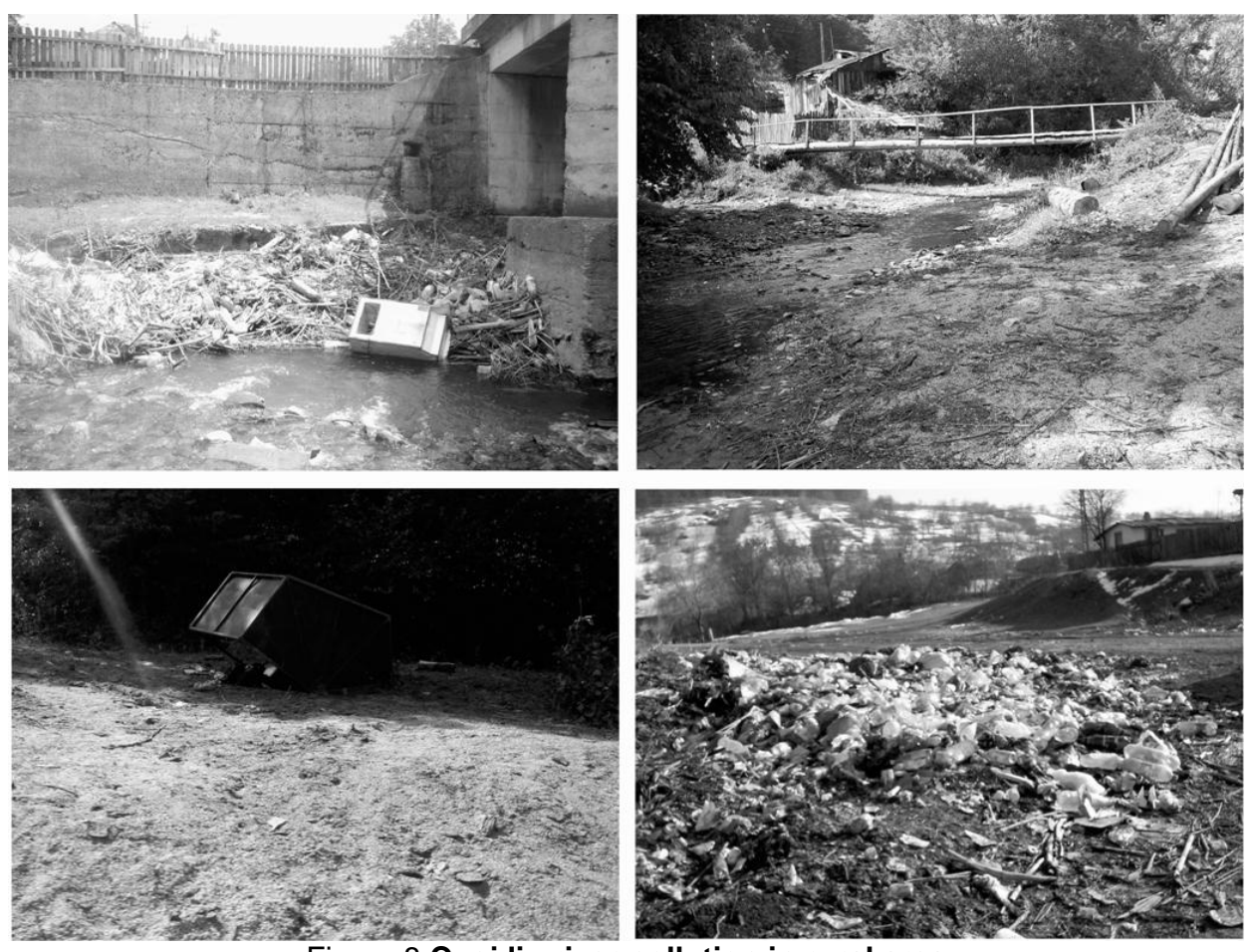

Figure 8 Cuejdiu river pollution in rural area

\section{CONCLUSIONS}

The improper activities practiced in proximity to water resource change its quality, with consequences on living standards. Samples analyzed highlight this aspect, Cuejdiu river water quality being classified into class III due to chlorides indicator, which has very high values on the entire analyzed area.

Vulnerability to anthropogenic actions is a determining factor in maintaining the ecological balance of aquatic ecosystems. Educating residents and their direct involvement in environmental activities is the most important thing about causing pollution problems.

\section{ACKNOWLEGMENTS}

Articolul prezintă rezultatele cercetării susținută financiar din fonduri social europene gestionate de Autoritatea de Management pentru Programul Operațional Sectorial Dezvoltarea Resurselor Umane [grant POSDRU/107/1.5/S/78342].

\section{REFERENCES}

Costică, C., 2007 - Ecologie şi protecția mediului, Editura Sitech, Craiova, p. 281

Ghiurcă, A.A., 2012 - Environmental education in rural areas - a real support for sustainable development, volumul Simpozionului Ştiintific Internațional "Horticultura - ştiință, calitate, diversitate şi armonie", 24-26 mai 2012, Facultatea de Horticultură, laşi, in press, p. 2,

Pohoață, I., 2003 - Filosofia economică şi politica dezvoltării durabile, Editura Economică, Bucureşti, p. 28
Soroceanu, V., 2000 - Creşterea economică şi mediul natural, Editura Economică, Bucureşti, p. 220

Szőcs, A., 2010 - Caracterizarea regimului de oxigen al apei râurilor din bazinul superior şi mMijlociu al Mureşului, Conferința Aerul şi Apa - Componente ale mediului, Universitatea Babeş-Bolyai, Catedra de Geografie Fizică şi Tehnică, p.396

Ungureanu, I., 2003 - Geografia mediului, Editura Editura Ministerul Educației şi Cercetării, Bucureşti, p. 106-111. 